\title{
Un Hombre Puede Hacerlo, pero ¿̇una Mujer? A Critical Discourse Analysis Showing how Mexican Women might be Machistas
}

\author{
Silvia Monserrat Pacheco Constantino \\ University of Guanajuato, MEXICO \\ Division of Social Sciences and Humanities
}

Received: 1 June 2020 - Accepted: 25 August 2020 • Published Online: 31 October 2020

\begin{abstract}
Thousands of women die every day all over the world due to violence. Mexico is a country in which it is believed that machismo is one of the reasons why women are violated and murdered. There is the stereotype of believing that the female gender is being mistreated directly by men. However, this study aimed to show how women express themselves with a negative connotation against their own gender. Perhaps, females portrait themselves as feminists or women defenders. Nonetheless, their language states their true position. This project employed a critical discourse analysis under the use of Fairclough's model. The results demonstrated how the discourse employed by the participants highlighted a machista perception towards women.
\end{abstract}

Keywords: critical discourse analysis, machismo, violence against women, female perceptions.

\section{Introduction}

In 2019, 976 women were victims of femicide in Mexico. In January of 2020, 10 women were murdered every day in my country. Corradi et al. (2016) highlight the use of the word femicide as to "raise awareness that violent death of women was a crime per se, not to be confused with the gender-neutral term homicide" (p. 976). I define femicide as a hate act towards women for the fact of being it. The big question is: Who is it guilty? Many people blame men and many make women responsible of their own death. Perhaps, Mexicans think that women should act, work, dress, and even walk in a certain way. If they do not do it, then they deserved to die. I blame machismo. Mosher (1991) states that machismo is represented by hypermasculinity in where male gender is believed to be socially superior to the female gender. Initially, it could be thought that men are the only gender to be machista. However, women have demonstrated through the years that they agree to some extend to the machista ideology. This study presents a critical discourse analysis (CDA) with the aim of analyzing women's discourse which demonstrates that their support machismo.

(C) Authors. Terms and conditions of Creative Commons Attribution 4.0 International (CC BY 4.0) apply. Correspondence: Silvia Monserrat Pacheco Constantino (MA student), University of Guanajuato, Division of Social Sciences and Humanities, Lascurain de Retana \#5, Guanajuato, MEXICO, 3600o. E-mail: monsepacheco3108@gmail.com. 
- Mexican women discourse can portrait hidden messages that might support ideologies corresponding to machismo.

- The discourse of both participants are constructed with predominantly behavioral and mental processes.

- Socio-historical conditions affect differently the results obtained from the verbal sign analysis.

- Two aspects of social practices in critical discourse analysis were highlighted in the discussion of analysis: power relation and ideologies.

\section{Literature review}

\subsection{Mexican machos}

Machismo is a word that is used to define violent attitudes and behaviors towards women. This set of attitudes raise the difference between men and women. However, these dissimilarities make the female gender inferior in this comparison.

An interesting analysis of the origin of machismo is the one stated by Paredes (1967) who mentions the following:

Machismo has its origins in the Spanish conquest, when Hernan Cortes and his conquerors arrived in Mexico and raped the Aztec women. From this act of violence, the mestizo hates and envies the Spanish father and despises the Indian mother since they were born (p. 65).

Mestizos suffered from discrimination because they did not belong to the Spaniards neither to the Aztecs. They were not recognized by their Spanish fathers and it is unknown whether the Aztec women were raped only by one man or by many. The conquerors did not belong to one place. Consequently, they left the land in which they had rapped the Aztecs abandoning the women and their children. The mestizos perhaps found their way out their feelings by blaming their mothers.

Paredes (1967) introduces the idea of the origin of machismo and highlights the importance of taking into consideration the time in which all of this happened. If machismo in Mexico was originated from the acts of raping indigenous women in Mexico, it would mean that this phenomenon has been around the country for about four centuries. Perhaps, people are more aware these days of the attitudes that lead men to act in certain way which will categorize them as machistas. I rather use the word people instead of being specific to men because it is a reality that not only men are machistas.

According to Hölz (1992), the philosophy of machismo claims that the natural disposition of women is determined by weakness, the need for protection, gentleness and charity. If women grow up thinking that their responsibilities are at home to be a housewife, a mother and to take care of their husbands, they are also being machistas. Orozco (2008) remarks how women have been seen from the macho perspective:

From a considerably long period of time there has been a kind of arcaded domination towards women, the so-called "weaker" sex. In general terms, this way of conceiving the female gender has come from yesteryear, due to the cultural practices of the peoples, mainly indigenous (p. 9).

This study analyses the discourse of Mexican women; therefore, it is relevant to consider the idea of including how machismo perceives the female gender. I intend to prove machismo is not men exclusive. Women who think that they should live under the characteristics mentioned by Orozco (2008) and Hölz (1992) should also be considered machistas. 


\subsection{Femicide in a Mexican context}

I decided to include a section dedicated to femicide because I consider that machismo has a strong impact on society. Also, these two topics are related because it is a reality that machismo can lead men to kill women. I selected the definition of feminism provided by Corradi et al., (2016) due to its suitability for the Mexican context.

The translation of femicide into Spanish was promoted by Marcela Lagarde ... along with other Mexican researchers, such as Monárrez Fragoso, pushed for a translation that did not adopt the English term "femicide" literally. Feminicidio (instead of femicidios) tends to be employed in Spanish as the one notion that best expresses the violent death of women and girls, because it incorporates the semantic field of connivance of state and public institutions as relevant factors in femicide (p. 984).

Many families in the country lose their daughters, mothers, nieces, cousins, aunts, etc. due to femicide. The translation that was provided is a powerful statement that describes the violent deaths that many women suffer. I believe this definition suits not only Mexican women, but also females all over the world.

Olivera (2006) states that the killings would belong to unknown assailants. Nonetheless, "in the majority of cases, women are murdered by someone known to them or related through work, family, or romantic involvement" (p. 105). I want to emphasize that language plays a key role in these cases. Maybe, people can be able to identify whether a relative or a friend of the family intends to harm someone by their expressions. Perhaps, it is not that language can show that a person is about to commit a crime, but their attitudes towards women can certainly be inferred. It is not only men who can express themselves as machistas. hidden messages:

Olivera (2006) illustrates how the inequalities against women can portrait direct or

Violence against women, an expression of male power, is present in various forms and degrees throughout their lives ... In all societies the cultural models for being a woman assign positions to women ... creating real and symbolic inequalities... These inequalities are expressed in direct or hidden messages... violence against women progressively develops from insinuations, offensive comparisons, harassment, threats, verbal intimidation, abuse, irresponsibility, betrayals... (p. 105)

Femicides is a consequence of violence against women. There are several factors that lead men to end the life of a female. However, these aspects can be identified before the situation escalades. I do not want to imply that language can provide a solution for femicides, but it could help to have a faster identification of a person who is machista. For me, machismo is the first step on the ladder of femicide.

\subsection{Feminism over the years in Mexico}

The term feminism arose from the need of women equality. According to AcostaAlzuru, the words feminism and feminist are concepts with a strong and controversial message. She states that "Latin American women's movements have played a key role in improving the political, social, and legal conditions for women in the region" (Acosta-Alzuru, 2003: 269). Mexico has not been the exception to this rule. The history of feminism in Mexico dates back to the revolution of the country. As Leland (2010) cites: "The Porfiriato witnessed the emergence of the modern feminist movement that would extend into the later twentieth century both in forms of organization and cases for argument of their positions" (p. 10).

Back in those days, the "ideal of womanhood in Mexico consisted of the woman who only used her education to better herself as a wife and mother" (Leland, 2010: 7). This idea has 
change over the years. However, it has not been an easy path because even to current time, some people still have misconceptions regarding the role of the woman in the society. During this paper, I will be showing how some Mexican women portrait themselves as machistas when mentioning some aspects they consider a woman should follow to belong to the society. Woman discourse can show that they agree to some standards that belong to the machista ideology.

The evolution of the feminism in Mexico started rising attention by the end of the 80's and 90's when Mexican feminists had started to participate in the public institutional sphere, a domain that they had not considered a suitable space for action in the 1970s (Bartra et al., 2000, as cited in Chen, 2019). Additionally, women start to conduct studies in the area as well as directing feminist groups and organizations.

Nowadays, more women protest for their rights. There are several factors that have made Mexican women fight for their equality in society. Perhaps, one of the main reasons that has motivated them to go out to the streets to protest is the increase in the number of femicides in the country. More females are joining the organizations and groups to disprove the misconception of their role in the society.

The next section will describe the methodology that was followed in order to analyze the discourse of two Mexican women.

\section{Methodology: Critical discourse analysis}

This paper aims to analyze the discourse of two women who claimed defending women's right. In order to conduct this examination, critical discourse analysis (CDA) was selected as part of the methodology for this study. Two aspects of social practices in critical discourse analysis were highlighted and taken into consideration: power relation and ideologies.

Fairclough (2001) remarks the explanation of this research method as following:

CDA analyses texts and interactions, but it does not start from texts and interactions.

It starts rather from social issues and problems, problems which face people in their social lives, issues which are taken up within sociology, political science and/or cultural studies (p. 26).

In addition, Janks (1997) explains that every social practice provides with a historical practice which relates it to language. In the case of this paper, femicide and machismo are social issues that are relevant and affect Mexicans' everyday life. I implemented CDA as the research methodology of this paper based on Fairclough's (1989; 1995) model which is explained in the following table.

Table 1. Fairclough's (1989, 1995) model for CDA

\begin{tabular}{|l|l|l|}
\hline $\begin{array}{l}\text { Inter-related dimensions } \\
\text { of discourse }\end{array}$ & Application & Different kind of analysis \\
\hline The object of analysis & $\begin{array}{l}\text { including verbal, visual or } \\
\text { verbal and visual texts }\end{array}$ & Text analysis (description) \\
\hline $\begin{array}{l}\text { The processes by means of } \\
\text { which the object is } \\
\text { produced and received }\end{array}$ & $\begin{array}{l}\text { writing/ speaking/designing } \\
\text { and reading/listening/viewing } \\
\text { by human subjects }\end{array}$ & $\begin{array}{l}\text { Processing analysis } \\
\text { (interpretation) }\end{array}$ \\
\hline $\begin{array}{l}\text { The socio-historical } \\
\text { conditions which govern } \\
\text { these processes }\end{array}$ & & Social analysis (explanation) \\
\hline
\end{tabular}

Note: Information retrieved from Janks (1997).

For the analysis employed in this paper, the subjects of the study were selected. The text analyzed were fragments of conversations between women in Mexico in a daily routine. It is 
relevant to mention that the participants were against violence and machismo. However, verbal signs were identified in which they support this ideology, contrary to what they stated at the beginning of the conversation. After the text was analyzed and the verbal signs were identified, the social analysis was carried out in order to provide an explanation of why it was thought that the participants contradict themselves in their discourse.

Figure 1 represents the three dimensions that were the reference for the conducted analysis of the abstracts in this research.

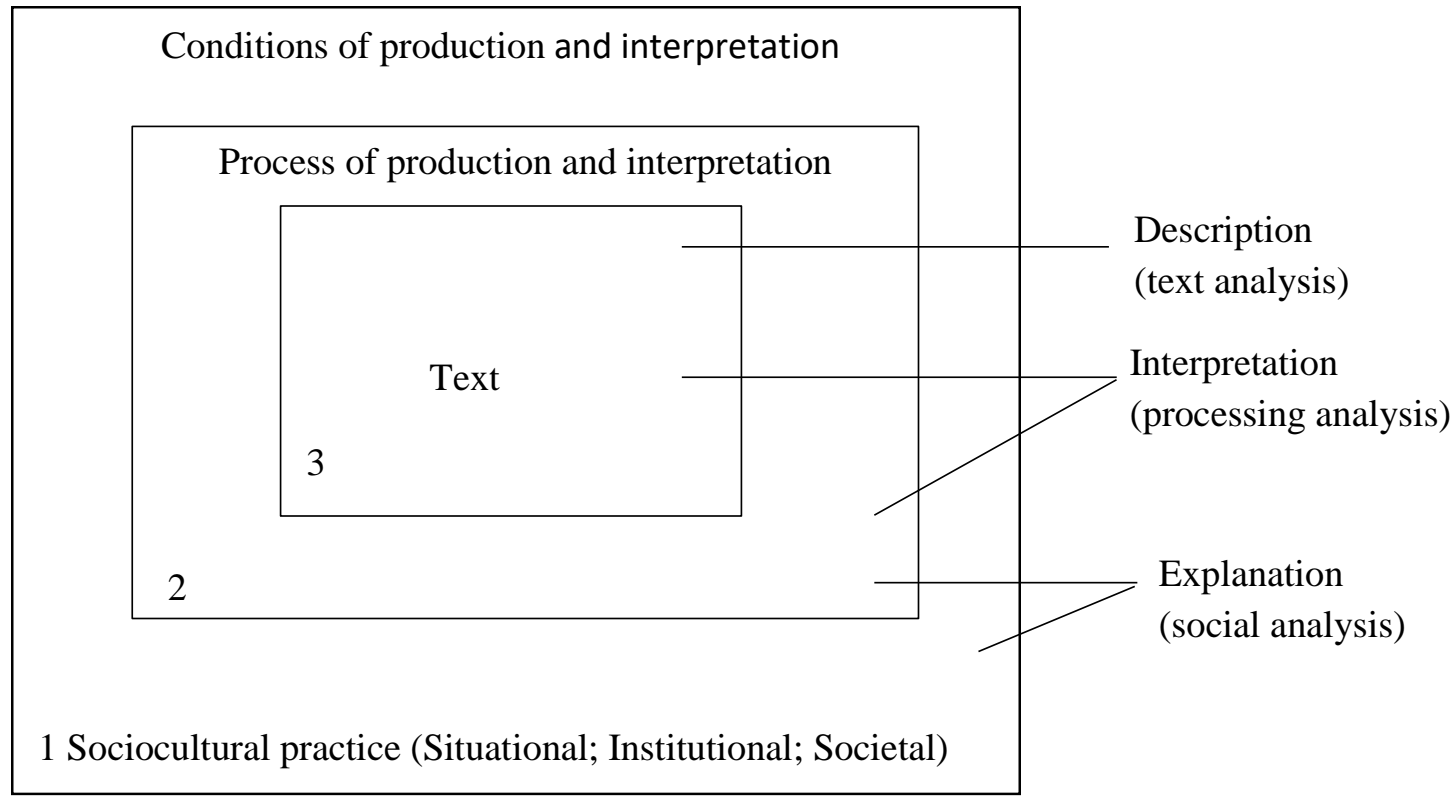

Note: Retrieved from Janks (1997: 330).

Figure 1. Fairclough's dimension of discourse and discourse analysis

The next section will present the findings following the discourse analysis model of Fairclough $(1989,1995)$ which was represented in Table 1 and Figure 1 . It will be referred to them in order to explain some of the features identified in the analysis.

\section{Results of the analysis}

For this section, I discuss the findings following the discourse analysis model of Fairclough $(1989,1995)$. As it was presented in the previous section, this model consists of three stages. First, I will present a textual analysis of the abstracts of the conversations between the participants as a description. Then, I explain the processes by the recognition of verbal signs in which I interpret the text. Finally, I analyze the socio-historical conditions related to the identified issue.

\section{1 Textual analysis}

As it was mentioned in the methodology section, the texts employed for the analysis of this paper were abstracts of a conversation between two different participants. There are two women in their 50's who are neighbors and maintain a close friendship. They know each other's family. Therefore, they talk about personal topics. In Mexico, perhaps, it is common to comment between friends about family issues and experiences. Both women portrait themselves as women 
defendants. They are mothers of one son and one daughter. They believe both of their children should have the same rights and opportunities.

In the linguistic text, the participant 1 retells an experience that she lived a few weeks ago as the following:

Me sentí muy incómoda porque... ¿̇si ubicas a las vecinas, las que son lesbianas que viven aquí a la vuelta? Bueno, pues un día fui a la tienda a comprar y estaba una de ellas. Y tú sabes como me visto con mi short y mi blusa de tirantes. Pues me echó una mirada que dije iay no qué horror! Un hombre te morbosea de por sí, pero cuna mujer? iNo! Me sentí abusada. / I felt extremely uncomfortable because... Do you know the neighbors who are lesbians that live right around the corner? Well, this other day, I went to the store to buy something and one of them was there. And you know how I usually dress with a short and a tank top. Well, she looked at me head to toes and I had a terrible feeling. It is normal that a man looks at you with desire, but a woman? Hell no! I felt abused.

The participant did not used many adjectives. However, she expressed herself using these adjectives after the verb be, have, and feel: lesbians, terrible, and abused. Consequently, she relates negative feelings with her experience. She portrays a negative image towards a lesbian woman staring at her and having lustful thoughts. She relates the adjective lesbian with a terrible experience which made her feel abused. Perhaps, she was not sure whether her neighbor would stare at her because of that reason, but she immediately assumed it. She reacted negatively because of the fact that her neighbor is lesbian. Despite, I was not able to present a picture of the situation, I was present as a researcher when she was retelling her story. I could perceive by the tone of her voice that she was disgusted. Additionally, she perceives the idea of men having the right of staring at her no matter the intention they have.

Regarding the participant 2, I selected the following abstract in which she defends her son's position in his marriage:

El otro día estaba hablando con mi hijo porque él y su esposa pelean mucho. Yo no sé qué va a pasar si se separan. Yo lo pienso por mi nieto. Cuando se pelearon yo pensaba que mi hijo se estaba viendo con otra muchacha. Y a mí me gustaría tener más nietos en el futuro. No me importa con quién los tenga porque si son hijos de tu hijo los tienes que aceptar aunque él ande con otra mujer / The other day I was talking to my son because he and his wife fight a lot. I do not know what is going to happen if they split up. I think about it because of my grandson. When they fought, I thought my son was cheating on my daughter-in-law. I would really like to have more grandchildren in the future. I do not care with whom my son has them. I mean, if they are your son's children you must accept them no matter what. It does not matter if he is dating someone else besides his wife.

In the text, the noun "son" is constantly repeated. She states her indifference towards the woman his son is married to. She employs the modal verb "must" to emphasize the feeling of obligation towards being responsible of accepting and taking care of her grandchildren. She does not show empathy towards her daughter-in-law. She mentioned her to provide the context. However, the participant highlights her position in this situation. Also, the use of the personal pronoun is present in most of the sentences. This shows that her opinion is based on what she personally desires or wants.

\subsection{Verbal signs analysis}

Janks (1997) introduces a check list based on Halliday's (1985) and Fairclough's (1989) to provide a complete text analysis. The check list presents six features as following: lexicalization; patterns of transitivity; the use of active and passive voice; the use of nominalization; choices of 
mood; choices of modality or polarity; the thematic structure of the text; the information focus; and cohesion devices.

I identified that in both abstracts the text was represented through verbs in the majority of it. Therefore, I decided that I wanted to analyze the verbs in the patterns of transitivity. In Figure 2, I represent the criteria I followed for the analysis of verbal signs through the patterns of transitivity.

Types of doing Material processes: actor + goal

Doing: e.g. Parents sometimes hit children. (active voice)

Doing to: e.g. Small babies should not be hit. (passive voice)

Creating: e.g. The investigator does not have to make inferences.

Saying Verbal processes: sayer + what is said + (receiver)

e.g. One of the workers suggested that I try some brew.

Sensing Mental processes: Senser + phenomenon

Feeling: e.g. I like that one. The children feel angry.

Thinking: think, know, understand, interpret, etc.

Perceiving: saw, notice, stared at, etc.

Types of being Relational processes

Being: $\mathrm{x}$ is y e.g. Child abuse is terrible (or a terrible thing).

Types of behaving Behavioral processes

Physiological- breath, dream, sleep.

Psychological- smile, laugh.

Things that exist or happen Existential processes

e.g. The world is round. There was a man at the door.

Note: Retrieved from Janks (1997: 336).

Figure 2. Halliday's (1985) explanation of transitivity

Figure 2, Janks (1997) represented the six different types of transitivity proposed by Halliday's (1985). "To do a transitivity analysis it is necessary to identify every verb and its associated process "(Janks, 1997: 337).

I followed the processes of identifying the verbs and their associated processes. The results are illustrated in Table 2 and Table 3. 
S. M. Pacheco Constantino - Un Hombre Puede Hacerlo, pero ċuna Mujer? A Critical Discourse ...

Table 2. Types of transitivity of the verbs

\begin{tabular}{|c|c|}
\hline \multicolumn{2}{|c|}{ Abstract Participant 1 } \\
\hline Activity & Process \\
\hline Felt & Mental \\
\hline Know & Mental \\
\hline Are & Relational \\
\hline Live & Behavioral \\
\hline Went & Behavioral \\
\hline Buy & Material \\
\hline Was & Relational \\
\hline Know & Mental \\
\hline Dress & Behavioral \\
\hline Looked & Behavioral \\
\hline Had & Relational \\
\hline Looks & Behavioral \\
\hline Felt & Mental \\
\hline
\end{tabular}

Table 3. Types of transitivity of verbs

\begin{tabular}{|c|c|}
\hline \multicolumn{2}{|c|}{ Abstract Participant 2} \\
\hline Activity & Process \\
\hline Was talking & Behavior \\
\hline Fight & Behavior \\
\hline Know & Mental \\
\hline Going to happen & Behavior \\
\hline Split up & Behavior \\
\hline Think & Mental \\
\hline Fought & Behavior \\
\hline Thought & Mental \\
\hline Was cheating & Behavior \\
\hline Would like to have & Relational \\
\hline Do not care & Mental \\
\hline Has & Relational \\
\hline Are & Relational \\
\hline Must accept & Mental \\
\hline Does not matter & Material \\
\hline Is dating & Behavior \\
\hline
\end{tabular}

Table 2 and Table 3 demonstrate that the discourse of both participants are constructed with predominantly behavioral and mental processes. Figure 2 refers to behavioral processes as physiological and psychological features which means these women's discourse is being affected in those areas. Also, it can be observed that both participants construct their verbal transitivity with a low number of material processes. The first participant only used one and the second participant did not used any. These results suggest that both women do not act on their own. If we go back to Figure 2, it is explained that material processes imply the act of doing and in both cases they do not state verbs of act. Perhaps, that could answer why participant 2 was so involved in her son's life. She expressed her opinion as if she was part of the marriage and she acts as if her son needed to be taken care of.

In the case of participant 1 , she felt abused by the fact that a woman stared at her. Her transitivity of verbs shows how she is being affected by psychological features. In the next section, I will relate this analysis to the social context to provide a further explanation of why she felt that way.

\subsection{Discussion of the socio-historical conditions}

In this section, I discuss the results and provide a justification with social conditions. Fairclough and Wodak (1997) describe critical discourse analysis as a social practice which means that language and context constitute a relevant aspect in the analysis. As I mentioned in the methodology section, I identified that the results of this project are related to power and ideologies.

On one hand, participant 1 expressed her disagreement towards being stared at by a women but normalizes the idea of men behaving the same way. She portraits herself as a women defendant. However, when it comes the time to talk about lesbianism, and women freedom she responded awkwardly to these type of situations. As the text analysis showed, her discourse was constituted mainly by behavioral and mental processes. This means that she is more in touch with her feelings and that her discourse is affected by her way of thinking. The literature highlights how women have been discriminated by men. The male gender should not carry all the responsibility towards women's discrimination because as the results imply, women also judge each other. 
On the other hand, participant 2 normalizes the perceptions that correspond to machismo. She stated that she would love her grandchildren no matter who their mother is. She stated than even if his son cheated on his wife, she would stand by his side to support him. Again, I recall the analysis of the text in which behavioral and mental processes are dominating her discourse. Perhaps, past experiences affected her psychological and emotional thoughts which is now related directly to her discourse.

It was disappointing to realize that both women's discourse lacked of material processes. This type of process states that a person is capable of doing and creating. The results associated this deficiency with the absence of a person being able to act under their own decisions. As it was presented in the literature, Mexican women have struggled to stand by their own. For many years, they have depended on men. First, when a woman is born, they depend on their fathers and when they get married they depend on their husbands.

I do not want to imply that all Mexican families develop in the same way. Nonetheless, it is culturally known that machismo has influenced many families all over the country. Machismo perceives the men as the strongest family member and the one who needs to take care of the family. When a son becomes adolescence, it is time for him to work and help the father to take care of the family members specially women.

\section{Conclusion}

Through Fairclough's three-dimensional model of critical discourse analysis, I have proved how women might support machismo through language. The participants expressed their feminist position. However, their discourse was identified as the opposite. I would not conclude that they support machismo in a 100\% level, but it is alarming that they are being so close-minded in these important topics.

The purpose of this article is not to attack women, but to raise awareness on how discourse is relevant and how it can portrait hidden messages and meanings. The results of this analysis compile the disagreement between what a person might express as their way of thinking and their actual beliefs.

As I mentioned in the discussion of the socio-historical conditions, I do not generalize, but I refer to the context in which this study was conducted. There would always be women whose history and past experiences keep them from unleashing themselves from the oppressor. Mexican women have fought for their rights over the years and we will continue fighting until we make a change in history.

\section{Acknowledgements}

First, I would like to thank the University of Guanajuato for accepting me as part of their community of students in the master's degree program. I am beyond grateful for the opportunities that all my professors have given me to work on diverse projects. I would also like to express my gratitude to the professor Troy Crawford Lewis who encouraged me to write this article and publish it.

This research did not receive any specific grant from funding agencies in the public commercial, or not-for-profit sectors.

The author declares no competing interests. 


\section{References}

Acosta-Alzuru, C. (2003). "I'm not a feminist... I only defend women as human beings": The production, representation, and consumption of feminism in a telenovela. Critical Studies in Media Communication, 2O(3), 269-294.

Chen, Y. Z. (2019). Early activism and work arrangements of young feminists in Mexico City. Journal of Youth Studies, 22(4), 457-472 https://doi.org/10.1080/07393180302775

Corradi, C., Marcuello-Servós, C., Boira, S., \& Weil, S. (2016). Theories of femicide and their significance for social research. Current Sociology, 64(7), 975-995.

https://doi.org/10.1177/0011392115622256

Fairclough, N. (1989) Language and power. Longman.

Fairclough, N. (1995) Critical discourse analysis. Longman.

Fairclough, N. (2001). Critical discourse analysis. In A. McHoul \& M. Rapley (Eds.), How to analyze talk in institutional settings: A casebook of methods (pp. 25-38). A\&C Black.

Fairclough, N., \& Wodak, R. (1997). Critical discourse analysis. In van Dijk (Ed.), Discourse studies: A multidisciplinary introduction (pp. 258-284). Sage.

Hölz, K. (1992). El machismo en México. Sobrevivencia y rechazo de un tópico sociocultural. Iberoamericana, 2(46), 33-41.

Janks, H. (1997). Critical discourse analysis as a research tool. Discourse: Studies in the Cultural Politics of Education, 18(3), 329-342.

Leland, M. (2010). Separate Spheres: Soldaderas and feminists in revolutionary Mexico (Doctoral dissertation). The Ohio State University.

Mosher, D. (1991) Macho men, machismo, and sexuality. Annual Review of Sex Research, 2(1), 199-247. http://dx.doi.org/10.1080/10532528.1991.10559871

Olivera, M. (2006). Violencia femicida: Violence against women and Mexico's structural crisis. Latin American Perspectives, 33(2), 104-114. https://doi.org/10.1177/0094582X05286092

Orozco, W. (2008). El machismo en México y su esencia. Revista Entreverando, 2(2), 8-11.

Paredes, A. (1967). Estados Unidos, Mexico y el machismo. Journal of Inter-American Studies, 9(1), 65-84. https://doi.org/10.2307/165157 